\title{
Reduced expression of catenin subtypes is a potential indicator of unfavorable prognosis in esophageal squamous cell carcinoma
}

\author{
TADAHIRO NOZOE, TSUNEHIRO OYAMA, HIDETAKA URAMOTO, MISTUHIRO TAKENOYAMA, \\ TAKESHI HANAGIRI, KENJI SUGIO and KOSEI YASUMOTO
}

\begin{abstract}
Second Department of Surgery, University of Occupational and Environmental Health, 1-1 Iseigaoka, Yahata-Nishi Ward, Kitakyushu 807-8555, Japan
\end{abstract}

Received September 30, 2008; Accepted March 9, 2009

DOI: 10.3892/mmr_00000107

\begin{abstract}
Catenins are cytoplasmic proteins that play a pivotal role in cell adhesion. Conflicting results regarding the significance of their expression in esophageal squamous cell carcinoma (ESCC) have been reported. The expression of $\alpha-$, $\beta$ - and $\gamma$-catenin was examined using immunohistochemical methods in 69 samples collected from patients with ESCC who were surgically treated without any preoperative induction therapy. Reduced $\alpha$-, $\beta$ - and $\gamma$-catenin expression was observed in $48(69.7 \%), 36(52.2 \%)$ and $44(63.8 \%)$ ESCC samples, respectively. According to univariate analysis, ESCC patients exhibiting the reduced expression of $\beta$-catenin $(\mathrm{P}=0.028)$, $\gamma$-catenin $(\mathrm{P}=0.010), \alpha$ - and $\gamma$-catenin combined $(\mathrm{P}=0.047)$ or $\beta$ and $\gamma$-catenin combined $(\mathrm{P}=0.046)$ had a significantly more unfavorable rate of survival. Multivariate analysis demonstrated that the reduced expression of $\gamma$-catenin $(\mathrm{P}=0.015)$ as well as lymph node metastasis $(\mathrm{P}=0.015)$ could serve as independent prognostic indicators of unfavorable prognosis in ESCC patients. Reduced immunohistochemical expression of $\gamma$-catenin may thus prove to be a powerfull and useful predictor of prognosis in patients with ESCC.
\end{abstract}

\section{Introduction}

The migration of cancer cells from the cancer nest is an initial event in the formation of tumor metastasis (1). Previous investigations have demonstrated that the expression of adhesion molecules, which prevent cancer cells from detaching, is a potential indicator of favorable prognosis in patients and/or of less invasive behavior in gastrointestinal cancer types, including esophageal squamous cell carcinoma (ESCC) (2-4).

Among the various adhesion molecules, the expression of E-cadherin has primarily been investigated, and a significant

Correspondence to: Dr Tadahiro Nozoe, Second Department of Surgery, University of Occupational and Environmental Health, 1-1 Iseigaoka, Yahata-Nishi Ward, Kitakyushu 807-8555, Japan E-mail: paper7777@yahoo.co.jp

Key words: squamous cell carcinoma, esophagus, immunohistochemical expression, catenin subtype, prognostic indicator correlation between its expression and a favorable prognosis in cancer patients, including those with ESCC, has been reported (5-7).

Catenins ( $\alpha-, \beta$ - and $\gamma-)$ are cytoplasmic proteins that bind to the conserved tail of the epithelial E-cadherin molecule and play a crucial role in E-cadherin-mediated intracellular signal transduction and cell adhesion. The cytoplasmic domain of E-cadherin binds to $\beta$ - or $\gamma$-catenin, while $\alpha$-catenin binds to the E-cadherin - $\beta$ - and - $\gamma$-catenin complexes to maintain the cellular cytoskeleton (8).

While the immunohistochemical expression of $\alpha-, \beta$ - and $\gamma$-catenin in ESCC has been examined, the results reported regarding their clinicopathological significance for patient prognosis have been inconsistent $(5,6,9-13)$. The present study used surgically dissected samples of ESCC to investigate the immunohistochemical expression of $\alpha$-, $\beta$ - and $\gamma$-catenin in order to determine their combined effect on the prognosis of patients with ESCC.

\section{Patients and methods}

Patients and samples. Sixty-nine consecutive specimens of ESCC from patients surgically treated in our department between 1992 and 2003 were obtained. The study population consisted of 63 men and 6 women with a median age of 64 years (range 42-83). Preoperative induction therapy was not performed in any of the cases. Continuous follow-up of the patients was carried out following surgery for periods ranging from 1 month to 11 years and 3 months (mean 3 years). Patients who succumbed to ESCC were described as having succumbed to tumor-related death. Pathological features were described according to the Guidelines for Clinical and Pathologic Studies on Carcinoma of the Esophagus proposed by the Japanese Society for Esophageal Diseases $(14,15)$. Tumor stage was determined by the TNM Classification of Malignant Tumors prescribed by the International Union Against Cancer (16).

Immunohistochemical expression of $\alpha-, \beta$ - and $\gamma$-catenin. Sections $(4 \mu \mathrm{m})$ sliced from paraffin-embedded specimens were prepared on glass slides pre-coated with silane. After deparaffinization with xylene and washing in a graded series of ethanol, the sections were placed in Tris-buffered saline (TBS) for $10 \mathrm{~min}$. Endogenous peroxidase activity was blocked 
A

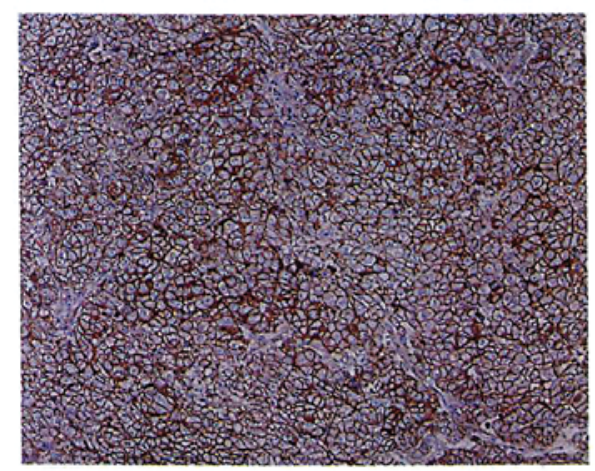

D

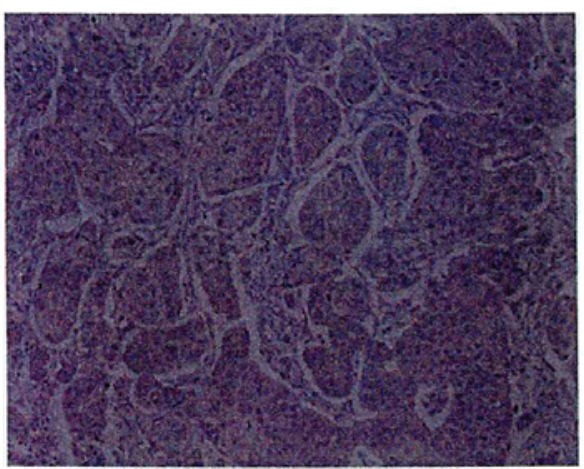

B

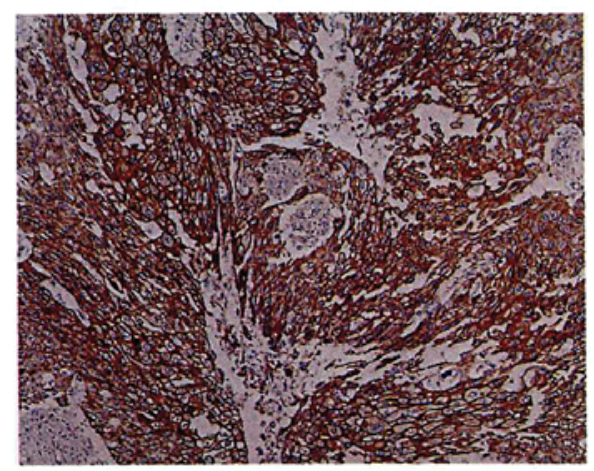

E

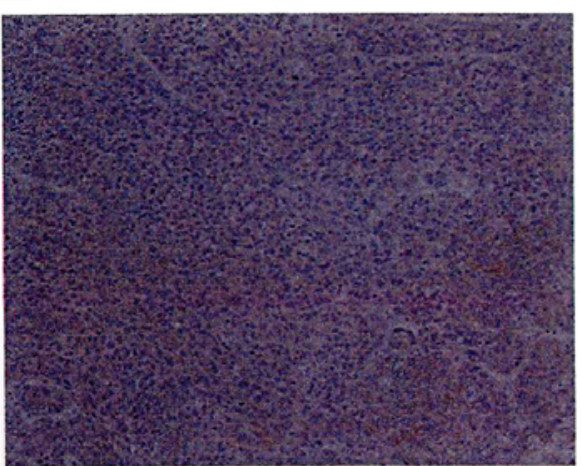

C

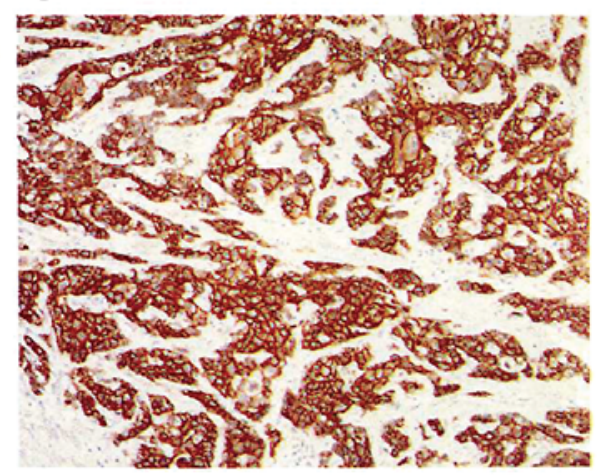

F

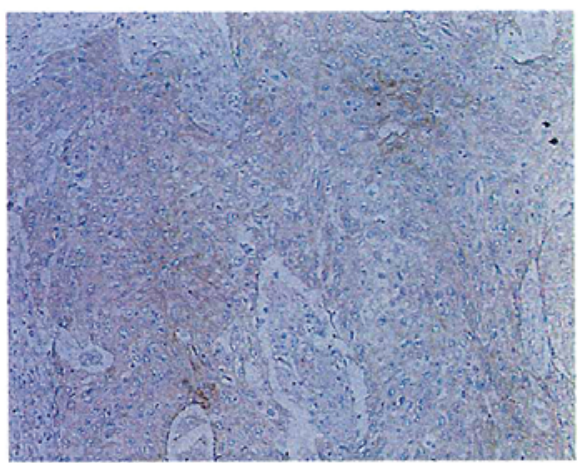

Figure 1. Representative sections showing catenin expression by immunohistochemistry. Preserved expression of (A) $\alpha$-catenin, (B) $\beta$-catenin and (C) $\gamma$-catenin. Reduced expression of (D) $\alpha$-catenin, (E) $\beta$-catenin and (F) $\gamma$-catenin.

for $10 \mathrm{~min}$ in TBS containing $0.3 \%$ of hydrogen dioxide, then the slides were placed in TBS. The sections were incubated with TBS containing $1 \%$ bovine serum albumin for $10 \mathrm{~min}$ to block the non-specific binding of the immunoreagents. After washing in TBS, the sections were incubated with 1:100 diluted mouse anti-human monoclonal $\alpha$-, $\beta$ - or $\gamma$-catenin antibodies (Invitrogen, Ltd.). All incubations were processed overnight at $4^{\circ} \mathrm{C}$. After washing in TBS, immunoperoxidase staining was performed using an EnVision antibody complex method (17) with an EnVision Kit (Dako Ltd., Tokyo, Japan). Finally, the localization of the proteins was visualized with diaminobenzidine tetrahydrochloride.

The expression of $\alpha-, \beta$ - and $\gamma$-catenin in ESCC was evaluated by criteria presented by Lin et al (5). Briefly, tumors in which $\geq 50 \%$ of the carcinoma cells expressed each catenin were classified into the preserved expression group, while tumors in which $<50 \%$ of the carcinoma cells expressed each catenin were classified into the reduced expression group. Representative staining patterns are shown in Fig. 1.

Statistical analysis. The $\chi^{2}$ test and Student's t-test were used to compare the clinicopathological data. Cumulative survival rates were calculated using the Kaplan-Meier method and survival curves were verified by the Mantel-Cox log-rank test. Multivariate survival analysis was calculated according to Cox's proportional hazards model in a forward stepwise manner. $\mathrm{P}<0.05$ was considered significant.

\section{Results}

Twenty-one ESCCs (30.4\%) displayed preserved expression of $\alpha$-catenin and $48(69.6 \%)$ exhibited reduced expression. No significant difference was observed between $\alpha$-catenin expression and the clinicopathological characteristics of the patients (Table I).

Thirty-three ESCCs (47.8\%) exhibited preserved expression of $\beta$-catenin and $36(52.2 \%)$ had reduced expression. No significant difference was observed between $B$-catenin expression and the clinicopathological characteristics of the patients (Table II).

Twenty-five ESCCs $(36.2 \%)$ had preserved expression of $\gamma$-catenin and $44(63.8 \%)$ exhibited reduced expression. No significant difference was observed between $\gamma$-catenin expression and the clinicopathological characteristics of the patients (Table III).

The correlation between the expression patterns of the catenin subtypes and patient prognosis was investigated by means of univariate analysis. The findings indicate that an unfavorable impact was had on survival by the reduced expression of $\beta$-catenin $(\mathrm{P}=0.028), \gamma$-catenin $(\mathrm{P}=0.010), \alpha$ - and $\gamma$ catenin combined $(\mathrm{P}=0.047)$ and $\beta$ - and $\gamma$-catenin combined $(\mathrm{P}=0.046)$ (Table IV).

Multivariate analysis revealed that reduced expression of $\gamma$-catenin $(\mathrm{P}=0.015)$ and lymph node metastasis $(\mathrm{P}=0.015)$ serve as independent prognostic indicators (Table V). 
Table I. Relationship between $\alpha$-catenin expression and the clinicopathological characteristics of the esophageal squamous cell carcinoma patients.

$\begin{array}{ccc}\substack{\text { Preserved } \\(\mathrm{n}=21)} & \begin{array}{c}\text { Reduced } \\ (\mathrm{n}=48)\end{array} & \text { P-value } \\ & \end{array}$

\section{Gender}

Male

Female

$\begin{array}{lrrr}\text { Age (years) } & 65.0 \pm 7.4 & 63.3 \pm 7.8 & 0.390 \\ \text { Tumor location } & & & \\ \quad \text { Upper } & 5(23.8) & 9(18.8) & 0.687 \\ \text { Middle } & 13(61.9) & 28(58.3) & \\ \text { Lower } & 3(14.3) & 11(22.9) & \end{array}$

Histologic classification

$\begin{array}{lrrrr}\text { Well } & 2 & (9.5) & 8(16.7) & 0.291 \\ \text { Moderately } & 17(81.0) & 30(62.5) & \\ \text { Poorly } & 2 & (9.5) & 10(20.8) & \end{array}$

Tumor depth

Tis, T1

$\mathrm{T} 2$

T3

T4

\begin{tabular}{|c|c|}
\hline $8(38.1)$ & $16(33.3)$ \\
\hline $1 \quad(4.8)$ & 8 (16.7) \\
\hline $8(38.1)$ & $15(31.3)$ \\
\hline $4(19.0)$ & 9 (18.7) \\
\hline
\end{tabular}

Lymph node metastasis

Positive

Negative

$11(52.4) \quad 29(60.4)$

$10(47.6) \quad 19(39.6)$

0.695

0.534

$\begin{array}{lrrr}\text { Positive } & 17(81.0) & 37(77.1) & 0.718 \\ \text { Negative } & 4(19.0) & 11(22.9) & \end{array}$

Venous invasion

$\begin{array}{lrrr}\text { Positive } & 9(42.9) & 26(54.2) & 0.387 \\ \text { Negative } & 12(57.1) & 22(45.8) & \end{array}$

Tumor stage

\begin{tabular}{llll}
0, I & $5(23.8)$ & $13(27.0)$ & 0.882 \\
II & $7(33.3)$ & $15(31.3)$ & \\
III & $9(42.9)$ & $20(41.7)$ & \\
\hline
\end{tabular}

\section{Discussion}

Tumor metastasis occurs due to the migration of tumor cells from the locoregional nest of the tumor. This migration is caused by reduced cell-to-cell adhesion and the proteolysis of the extracellular matrix by the tumor cells, lymphatic or vascular permeation of the cells, lodgment of the cells in distant organs, and by the proliferation of the tumor to form clinical metastatic foci (18).
Tis, T1

$\mathrm{T} 2$

T3

T4

Lymph node metastasis

Positive
Negative

$17(51.5) \quad 23(63.9)$

$16(48.5) \quad 13(36.1)$

0.298

Lymphatic permeation

$\begin{array}{lrr}\text { Positive } & 26(78.8) & 28(77.8) \\ \text { Negative } & 7(21.2) & 8(22.2)\end{array}$

0.919

Table II. Relationship between B-catenin expression and the chicopathological characteristics of the esophageal squamous carcinoma patients.

$\begin{array}{ccc}\text { Preserved } & \text { Reduced } & \text { P-value } \\ (\mathrm{n}=33) & (\mathrm{n}=36) & \end{array}$

$\begin{array}{rrr}28(84.8) & 35(97.2) & 0.097 \\ 5(15.2) & 1 \quad(2.8) & \\ 62.8 \pm 8.8 & 64.7 \pm 6.6 & 0.294 \\ & & \\ 7(21.2) & 7(19.4) & 0.682 \\ 18(54.5) & 23(63.9) & \\ 8(24.3) & 6(16.7) & \end{array}$

$\begin{array}{rrrr}4(12.1) & 6(16.7) & 0.149 \\ 26(78.8) & 21(58.3) & \\ 3 & (9.1) & 9(25.0)\end{array}$

$15(45.5) \quad 9(25.0) \quad 0.368$

$4(12.1) \quad 5(13.9)$

$9(27.3) \quad 14(38.9)$

$5(15.1) \quad 8(22.2)$

Venous invasion

$\begin{array}{lll}\text { Positive } & 13(39.4) & 22(61.1) \\ \text { Negative } & 20(60.6) & 14(38.9)\end{array}$

0.070

Tumor stage

\begin{tabular}{llrr}
0, I & $11(33.3)$ & $7(19.4)$ & 0.484 \\
II & $11(33.3)$ & $11(30.6)$ & \\
III & $11(33.3)$ & $18(50.0)$ & \\
\hline
\end{tabular}

The adhesion molecule E-cadherin is known to play a crucial role in preventing the migration of tumor cells from the primary lesion (19). High expression of E-cadherin has been reported to be significantly correlated with a favorable patient prognosis and/or less invasive tumor potential (5-7).

The function of epithelial E-cadherin at the adhesion junction is dependent on the catenins for efficient cell-to-cell adhesion. Moreover, E-cadherin - catenin complexes have been known to play a pivotal role in maintaining cell-to-cell 
Table III. Relationship between $\gamma$-catenin expression and the clinicopathological characteristics of the esophageal squamous cell carcinoma patients.

$\begin{array}{ccc}\begin{array}{c}\text { Positive } \\ (\mathrm{n}=25)\end{array} & \begin{array}{c}\text { Negative } \\ (\mathrm{n}=44)\end{array} & \text { P-value } \\ & \end{array}$

\section{Gender}

Male

Female

Age (years)
Tumor location
Upper
Middle
Lower

Histologic classification

\begin{tabular}{|c|c|c|}
\hline Well & $4(16.0)$ & $6(13.6)$ \\
\hline Moderately & $20(80.0)$ & 27 (61.4) \\
\hline Poorly & 1 & $11(25.0)$ \\
\hline
\end{tabular}

Tumor depth

\begin{tabular}{|c|c|c|}
\hline Tis, T1 & $12(48.0)$ & $12(27.3)$ \\
\hline $\mathrm{T} 2$ & $2(8.0)$ & 7 (15.9) \\
\hline T3 & $6(24.0)$ & $17(38.6)$ \\
\hline $\mathrm{T} 4$ & $5(20.0)$ & 8 (18.2) \\
\hline
\end{tabular}

Lymph node metastasis

$\begin{array}{lll}\text { Positive } & 14(54.8) & 26(59.1) \\ \text { Negative } & 11(45.2) & 18(40.9)\end{array}$

Lymphatic permeation

$\begin{array}{lrr}\text { Positive } & 19(76.0) & 35(79.5) \\ \text { Negative } & 6(24.0) & 9(20.5)\end{array}$

Venous invasion

$\begin{array}{llll}\text { Positive } & 11(44.0) & 24(54.5) & 0.399 \\ \text { Negative } & 14(56.0) & 20(45.5) & \end{array}$

Tumor stage

\begin{tabular}{lrrr}
0, I & $9(36.0)$ & $9(20.4)$ & 0.375 \\
II & $7(28.0)$ & $15(34.1)$ & \\
III & $9(36.0)$ & $20(45.5)$ & \\
\hline
\end{tabular}

0.052
Table IV. Correlation of the expression patterns of the catenin subtypes with patient prognosis.

\begin{tabular}{lcccccc}
\hline & \multicolumn{2}{c}{ Preserved } & & \multicolumn{2}{c}{ Reduced } & \\
& $\begin{array}{c}\text { No. of } \\
\text { patients }\end{array}$ & $\begin{array}{c}\text { 5-year } \\
\text { survival } \\
\text { rate (\%) }\end{array}$ & & $\begin{array}{c}\text { No. of } \\
\text { patients }\end{array}$ & $\begin{array}{c}\text { 5-year } \\
\text { survival } \\
\text { rate (\%) }\end{array}$ & $\begin{array}{c}\text { Impact on } \\
\text { survival } \\
\text { (P-value) }\end{array}$ \\
\hline$\alpha$ & 21 & 59.6 & & 48 & 36.7 & 0.119 \\
$\beta$ & 33 & 58.4 & & 36 & 29.5 & 0.028 \\
$\gamma$ & 25 & 69.2 & & 44 & 31.0 & 0.010 \\
$\alpha+\beta$ & 12 & 64.6 & & 57 & 39.0 & 0.089 \\
$\alpha+\gamma$ & 14 & 68.8 & & 55 & 37.8 & 0.047 \\
$\beta+\gamma$ & 18 & 64.5 & & 51 & 36.6 & 0.046 \\
$\alpha+\beta+\gamma$ & 11 & 59.1 & 58 & 40.2 & 0.161 \\
\hline
\end{tabular}

adhesion and controlling tumor metastasis (20). Therefore, the reduced expression of catenin subtypes is a potential marker of unfavorable prognosis in patients with ESCC.

Reports have been published regarding the relationship between the expression of the catenin subtypes and the clinicopathological characteristics of patients with ESCC (5,6,9-13). These reports commonly emphasize the significance of the preserved expression of the catenin subtypes, in particular $\alpha$-catenin $(9,12,13)$ or $\beta$-catenin $(6,10,11)$, as an indicator of a more favorable prognosis for patients or of the reduced progressive potential of the ESCC tumor despite its aggressive potential.

While $\alpha$-catenin binds to the E-cadherin - $\beta$-catenin or - $\gamma$ catenin complex to maintain the cellular cytoskeleton (8), the expression of $\alpha$ - and $\beta$-catenin or $\alpha$ - and $\gamma$-catenin potentially exerts a synergistic function correlated with less invasive cellular behavior and/or a more favorable prognosis for patients with ESCC. However, in the present study, these parameters did not correlate with such clinicopathological factors.

Nevertheless, a reduction in the immunohistochemical expression of $\beta$ - or $\gamma$-catenin was an indicator of poor prognosis, according to univariate analysis. Moreover, multivariate analysis demonstrated that the reduced expression of $\gamma$-catenin as well as lymph node metastasis could serve as independent indicators of unfavorable prognosis in ESCC patients. As shown in Table IV, although the expression of plural catenin subtypes promoted the E-cadherin function of preventing the migration of tumor cells from the primary tumor nest of ESCC,

Table V. Factors independently associated with patient prognosis by multivariate analysis.

\begin{tabular}{lcccc}
\hline Variables & $\begin{array}{c}\text { Regression } \\
\text { coefficient }\end{array}$ & $\begin{array}{c}\text { Standard } \\
\text { error }\end{array}$ & $\begin{array}{c}\text { Odds ratio (95\% } \\
\text { confidence interval) }\end{array}$ & P-value \\
\hline Lymph node metastasis & 1.118 & 0.458 & $3.058(1.246-7.504)$ & 0.015 \\
Reduced expression of $\gamma$-catenin & 1.251 & 0.513 & $3.497(1.279-9.524)$ & 0.015 \\
\hline
\end{tabular}


it was not significantly correlated with a favorable prognosis in ESCC, according to multivariate analysis.

B-catenin is also known to be involved in the Wnt signaling pathway that regulates cellular differentiation $(21,22)$, while a decrease in the expression of $\beta$ - and $\gamma$-catenin was found to be closely correlated with poor differentiation in oral squamous cell carcinoma (23). In the present study, the preserved expression of $\gamma$-catenin proved to be significantly correlated with cellular differentiation, demonstrating that $\gamma$-catenin has a biological function in the regulation of cellular differentiation in ESCC.

Regarding this biological function, the significance of $\gamma$-catenin expression has been demonstrated by the correlation between the reduced expression of $\gamma$-catenin and the increase in lymph node metastasis observed in ESCC (5). Similar results regarding the significance of $\gamma$-catenin as a potential tumor suppressor protein in oral squamous cell carcinoma (24), non-small lung cancer (25) and bladder cancer (26) have been reported.

In conclusion, $\gamma$-catenin plays a significant role in sustaining the cytoskeleton of ESCC, which can be correlated with the metastasizing activity of ESCC. Reduced immunohistochemical expression of $\gamma$-catenin may thus prove to be a powerfull and useful predictor of prognosis in patients with ESCC.

\section{References}

1. Nagano $\mathrm{O}$ and Saya H: Mechanism and biological significance of CD44 cleavage. Cancer Sci 95: 930-935, 2004.

2. Nair KS, Naidoo R and Chetty R: Expression of cell adhesion molecules in oesophageal carcinoma and its prognostic value. J Clin Pathol 58: 343-351, 2005.

3. Ohno T, Aihara R, Kamiyama Y, Mochiki E, Asao T and Kuwano H: Prognostic significance of combined expression of MUC1 and adhesion molecules in advanced gastric cancer. Eur J Cancer 42: 256-263, 2006.

4. Ngan CY, Yamamoto H, Seshimo I, Ezumi K, Terayama M, Hemmi H, Takemasa I, Ikeda M, Sekimoto M and Monden M A multivariate analysis of adhesion molecules expression in assessment of colorectal cancer. J Surg Oncol 95: 652-662, 2007.

5. Lin YC, Wu MY, Li DR, Wu XY and Zheng RM: Prognostic and clinicopathological features of E-cadherin, alpha-catenin, beta-catenin, gamma-catenin and cyclin D1 expression in human esophageal squamous cell carcinoma. World J Gastroenterol 10: 3235-3239, 2004.

6. Zhao XJ, Li H, Chen H, Liu YX, Zhang LH, Liu SX and Feng QL: Expression of E-cadherin and beta-catenin in human esophageal squamous cell carcinoma: relationships with prognosis. World J Gastroenterol 9: 225-232, 2003.

7. Tamura S, Shiozaki H, Miyata M, Kadowaki T, Inoue M, Matsui S, Iwazawa T, Takayama T, Takeichi M and Monden M: Decreased E-cadherin expression is associated with haematogenous recurrence and poor prognosis in patients with squamous cell carcinoma of the oesophagus. Br J Surg 83: 1608-1614, 1996.

8. Van Aken E, De Wever O, Correia da Rocha AS and Mareel M: Defective E-cadherin/catenin complexes in human cancer. Virchows Arch 439: 725-731, 2001.

9. Setoyama T, Natsugoe S, Okumura H, Matsumoto M, Uchikado Y, Yokomakura N, Ishigami S and Aikou T: alpha-catenin is a significant prognostic factor than E-cadherin in esophageal squamous cell carcinoma. J Surg Oncol 95: 148-155, 2007.
10. Takayama N, Arima S, Haraoka S, Kotho T, Futami K and Iwashita A: Relationship between the expression of adhesion molecules in primary esophageal squamous cell carcinoma and metastatic lymph nodes. Anticancer Res 23: 4435-4442, 2003.

11. De Castro J, Gamallo C, Palacios J, Moreno-Bueno G, Rodriguez N, Feliu J and Gonzalez-Baron M: Beta-catenin expression pattern in primary oesophageal squamous cell carcinoma. Relationship with clinicopathologic features and clinical outcome. Virchows Arch 437: 599-604, 2000.

12. Nakanishi Y, Ochiai A, Akimoto S, Kato H, Watanabe H, Tachimori Y, Yamamoto $\mathrm{S}$ and Hirohashi S: Expression of E-cadherin, alpha-catenin, beta-catenin and plakoglobin in esophageal carcinomas and its prognostic significance: immunohistochemical analysis of 96 lesions. Oncology 54: 158-165, 1997.

13. Kadowaki T, Shiozaki H, Inoue M, Tamura S, Oka H, Doki Y, Iihara K, Matsui S, Iwazawa T and Nagafuchi A: E-cadherin and alpha-catenin expression in human esophageal cancer. Cancer Res 54: 291-296, 1994.

14. Japanese Society for Esophageal Diseases: Guidelines for the clinical and pathologic studies on carcinoma of the esophagus. Part I: Preface, general principles. Esophagus 1: 61-88, 2004.

15. Japanese Society for Esophageal Diseases: Guidelines for the clinical and pathologic studies on carcinoma of the esophagus. Part II: Pathologic Classification. Esophagus 1: 107-125, 2004.

16. Sobin LH and Wittekind C: TNM classification of malignant tumours. International Union Against Cancer. 5th edition. Wiley-Liss, New York, pp54-58, 1997.

17. Kammerer U, Kapp M, Gassel AM, Richter T, Tank C, Dietl J and Ruck P: A new rapid immunohistochemical staining technique using the EnVision antibody complex. J Histochem Cytochem 49: 623-630, 2001.

18. Beavon IR: The E-cadherin-catenin complex in tumour metastasis: structure, function and regulation. Eur J Cancer 36: 1607-1620, 2000.

19. Hirohashi S: Inactivation of the E-cadherin-mediated cell adhesion system in human cancer. Am J Pathol 153: 333-339, 1998.

20. Wijnhoven BP, Dinjens WN and Pignatelli M: E-cadherin catenin cell-cell adhesion complex and human cancer. Br J Surg 87: 992-1005, 2000.

21. Mizushima T, Nakagawa H, Kamberov YG, Wilder EL, Klein PS and Rustgi AK: Wnt-1 but not epidermal growth factor induces beta-catenin/T-cell factor-dependent transcription in esophageal cancer cells. Cancer Res 62: 277-282, 2002.

22. Korinek V, Barker N, Willert K, Molenaar M, Roose J, Wagenaar G, Markman M, Lamers W, Destree O and Clevers H: Two members of the Tcf family implicated in Wnt/beta-catenin signaling during embryogenesis in the mouse. Mol Cell Biol 18: 1248-1256, 1998.

23. Lo Muzio L, Staibano S, Pannone G, Grieco M, Mignogna MD, Cerrato A, Testa NF and De Rosa G: Beta- and gamma-catenin expression in oral squamous cell carcinomas. Anticancer Res 19: 3817-3826, 1999.

24. Ueda G, Sunakawa H, Nakamori K, Shinya T, Tsuhako W, Tamura Y, Kosugi T, Sato N, Ogi K and Hiratsuka H: Aberrant expression of beta- and gamma-catenin is an independent prognostic marker in oral squamous cell carcinoma. Int J Oral Maxillofac Surg 35: 356-361, 2006.

25. Winn RA, Bremnes RM, Bemis L, Franklin WA, Miller YE, Cool $\mathrm{C}$ and Heasley LE: gamma-catenin expression is reduced or absent in a subset of human lung cancers and re-expression inhibits transformed cell growth. Oncogene 21: 7497-7506, 2002.

26. Kashibuchi K, Tomita K, Schalken JA, Kume H, Takeuchi T and Kitamura T: The prognostic value of E-cadherin, alpha-, beta- and gamma-catenin in bladder cancer patients who underwent radical cystectomy. Int J Urol 14: 789-794, 2007. 